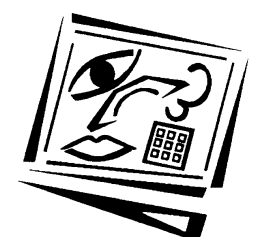

\title{
Factors leading to the adoption of a learning technology: The case of graphics calculators
}

\author{
Boris Handal \\ University of Notre Dame Australia \\ Michael Cavanagh, Leigh Wood and Peter Petocz \\ Macquarie University
}

\begin{abstract}
This paper reports on a case study which examined factors leading to the adoption of graphics calculators (GCs) by secondary mathematics teachers in the state of New South Wales, Australia. In total, 587 teachers of the General Mathematics Course (Years 11 and 12) participated in the study. The median teachers' stage of adoption of GCs was found to be at the "Understanding and application of the process" level, the third lowest on a six point scale. The results also indicate that competence is the most important factor in explaining stages of adoption, training the second most important, followed by personal interest in GCs as well as faculty support. Teachers' gender, teaching experience, educational qualifications and the number of GCs in schools were not found to be statistically significant. Qualitative analysis of teachers' open ended comments also shed light on the nature of the explanatory variables. The findings are relevant to curriculum development policy and the design of professional development programs, and has implications for the introduction of other technologies.
\end{abstract}

\section{Introduction}

New technology offers significant potential for enhancing the learning and teaching of mathematics at all levels. However if there is resistance to the adoption of technology then the potential will not be realised. This study considers the example of the adoption of graphics calculators (GCs) in upper secondary schools of New South Wales (NSW) as an example of the implementation of new learning technologies.

The use of GCs is a relevant case study in mathematics education because this technology permits students to enhance their spatial-visualisation skills, connect mathematical concepts in a richer context, and create greater understanding in particular topics such as functions and graphing (Geiger \& Goos, 1996). For nearly twenty-five years the implementation of GCs has been attempted by public and private education systems having large budgets spent for that purpose. These efforts include both the purchase of handheld class sets as well as professional development courses for mathematics educators. However, as Goos and Bennison (2008) indicate, "technology still plays a marginal role in mathematics classrooms and that educational policies, access to technology resources, and institutional support are insufficient conditions for ensuring effective integration of technology into teachers' everyday practice" (p. 103). 
Much of the research has focused on measuring the magnitude of the impact of GCs on students' academic performance as well as on teachers' attitudes in regard to GCs using descriptive statistics, chi-square and correlation analysis (Routitsky \& Tobin, 1998; Tobin, Routistsky \& Jones, 1999; Goos \& Bennison, 2008). However, there is a scarcity of literature on the possible explanatory effect of personal and environmental variables affecting the adoption of GCs using quantitative methods.

This study makes mainly use of multiple regression analysis as a tool for explaining and exploring relationships among variables (Osborne, 2000). Multiple regression is commonly used in the exploration of personal and environmental factors resulting in the adoption of technology (Atkin, Neuendorf, Jeffres \& Skalski 2003; Bussey, Dormody \& Van Leeuwen, 2000; Featherman \& Pavlou, 2003; Ndubisi, 2004; Shah Azam, 2007). This study adds to the existing body of GCs literature by presenting findings for explaining and identifying the most important factors leading to technological adoption.

\section{Background}

Studies on the impact of GCs in secondary education have revealed positive effects in the teaching and learning of mathematics. A body of research has related this positive impact to GC's capacity to connect graphical, algebraic and tabular representations of data and concepts to one another creating consequently a richer association of mathematical ideas (Alguire \& Forster, 1999, Hennessy, Fung \& Scanlon, 2001; Kwon, 2002; Portafoglio, 1998; Vonder Embse, 1992; Weber, 1998). Similarly, GCs are beneficial in situations where mathematical modelling is necessary. This is so because GCs empower learners to simulate hypothetical or real-life situations for investigation purposes thus producing student-centred environments (Arnold, 2004; Simonsen \& Dick, 1997). Studies conducted by Galbraith, Renshaw, Goos and Geiger (1999), and Cavanagh and Mitchelmore (2003) also reveal that these devices are able to generate richer communication among students and between students and teachers. When compared to desktop computers and other technologies, GCs stand out for their portability, compactness and low cost.

One important measure of the success of any educational reform is the extent to which it is adopted by teachers. Several schemes have been designed to evaluate the adoption of various technologies in educational settings (Cafolla \& Knee, 1995; EvansAndris, 1995; Hadley \& Sheingold, 1993; Russell, 1995). Russell (1995) conceptualised six stages of adoption following a qualitative research project investigating how school teachers enrolled in a postgraduate course learned to use electronic email while interacting with students on a specific learning task. Russell suggested that in adopting technology, teachers or any other adult may start at any point and will develop at their own rate through the following six stages: (a) awareness, (b) learning the process, (c) understanding and application of the process, (d) familiarity and confidence, (e) adaptation to other contexts, and (f) creative applications to new contexts.

Christensen (1997a; 1997b) adapted Russell's (1985) conceptualisation into a self-report scale designed to characterise teachers' adoption of educational technology in general, such as computers, emails, software and multimedia. The revised six stages of adoption in the Christensen's (1997b) Teachers' Attitudes toward Information Technology Questionnaire (TAT) are as follows: 
Awareness: I am aware that technology exists, but have not used it - perhaps I'm even avoiding it. I am anxious about the prospect of using computers.

Learning: I am currently trying to learn the basics. I am sometimes frustrated using computers. I lack confidence when using computers.

Understanding: I am beginning to understand the process of using technology and can think of specific tasks in which it might be useful.

Familiarity: I am gaining a sense of confidence in using the computer for specific tasks. I am starting to feel comfortable using the computer.

Adaptation: I think about the computer as a tool to help me and am no longer concerned about it as technology. I can use it in many applications and as an instructional aid.

Creative Application: I can apply what I know about technology in the classroom. I am able to use it as an instructional tool and integrate it into the curriculum. (Christensen, 1997b)

Fraze, Fraze, Baker and Kieth (2002) explored those stages of adoption among 310 agriscience teachers and found that the mean of stage adoption was between stage 4 (Familiarity/ confidence) and stage 5 (Adaptation). Other studies corroborated the findings of Fraze et al., such as Christensen and Knezek (2001) with 508 secondary teachers, and Christensen (1997b) with 25 elementary teachers. All these studies were carried out with United States samples.

As with the implementation of educational technology in schools, authors such as Knezek, Christensen, Hancock and Shoho (2000) and Hudson, Porter and Nelson (2008) are of the opinion that supporting teachers' beliefs in regard to the new technology are as important as curriculum resources and professional development. If teachers' beliefs correspond to the purposes of a particular innovation then it is apparent that change will be more likely follow. The converse is also true. When teachers resent the innovation, chances are that resistance will occur with subsequent lack of change (Handal \& Herrington, 2003). Educational reform in the field of educational technology is a complex process transcending the purchase of equipment and the provision of technical support. For an innovation to be sustainable it is necessary to ensure that issues such as enough professional assistance and preparation time are available (Ertmer, Addison, Lane, Ross, \& Woods, 1999; Handal, 2004; Pender, 2000).

Important advances in the teaching and learning of mathematics at the senior secondary school level have occurred in the last decade. Significant among these developments is the trend on fostering problem solving, modelling, use of technology and real life applications linked to central mathematical concepts and procedures. The increasing advocacy on those skills and on active construction of knowledge is exemplified in curriculum documents and examinations such as the Higher School Certificate Stage 6 (Years 11 and 12) Mathematics General Course which "provides a context within which to develop general competencies considered essential for the acquisition of effective, higher-order thinking skills necessary for further education, work and everyday life". (Board of Studies NSW, 1999, p. 12; Handal, Bobis \& Grimison, 2001). 
The Stage 6 General Mathematics course was introduced in 1999 to replace the former Mathematics in Society (Board of Secondary Education NSW, 1981) and the Mathematics in Practice (Board of Secondary Education NSW, 1989) courses. It is taught in Years 11 and 12 of the secondary curriculum. Nearly fifty percent of the students sitting the HSC are enrolled in the General Mathematics course.

The Stage 6 General Mathematics course (Board of Studies NSW, 1999) encourages the use of technologies in teaching and learning, particularly GCs and spreadsheets (Clarke, 2001; Grove, 2001), and technology is identified as a key competence. Throughout the syllabus document, there is advice for teachers on "the nature and suggested use of technology that is appropriate to the unit" (Board of Studies NSW, 1999, p. 13). GCs were also allowed for the first time in 2001 in a NSW Higher School Certificate examination formalising their adoption in the General Mathematics course which was introduced in 1999.

While this was a significant change for NSW, the use of GCs in external examinations had already taken place in other Australian states, such as Victoria (1997), South Australia (2000) and Western Australia (1998). Tasmania followed suit in 2005. Although Queensland does not have external examinations, GCs are allowed in all school examinations. Despite many resources and much effort, there is evidence that a large number of teachers are not using GCs in their classrooms, often due to lack of expertise, negative attitudes to these devices, or just a lack of an environmental support at the workplace (Goos \& Bennison, 2007, 2008; Thomas, Hong, Bosley \& delos Santos, 2008; Hudson, Porter \& Nelson, 2008).

\section{Research questions}

The present study investigated the impact of a number of educational variables which are traditionally examined in research dealing with implementing GCs and other digital learning technologies in the teaching and learning of mathematics. These include: geographical location, gender, educational qualifications, teaching experience, training, professional development modes, faculty support, perceptions of self competence, interest in using GCs in teaching and learning, and resources (Forgasz \& Prince, 2001; Loong, 2003; Forgasz, Griffith \& Tan, 2006; Routitsky \& Tobin, 1998; Thomas, 2006; Griffith, 2007). More specifically, the study sought to address the following research questions:

1. At which stage of adoption of GCs do NSW secondary mathematics teachers perceive themselves?

2. How are these stages of adoption related to

i. Teachers' gender?

ii. Teachers' interests towards GCs?

iii. Teachers' experience and academic qualifications?

iv. Teachers' perception of collegial support in regard to GCs?

v. Teachers' perception of self competence in using GCs?

vi. The availability of GCs in school?

vii.Teachers' previous professional development activities with GCs? 


\section{Methodology}

\section{Questionnaire}

A questionnaire (see Appendix) was designed to measure teachers' stages of adoption and attitudes towards GCs. Specific details about questionnaire design were reported previously by Handal, Chinnappan \& Herrington (2004). The questionnaire was adapted to the use of graphic calculators from the Teachers' Attitudes toward Information Technology Questionnaire (TAT) version 2.0 (Christensen, 1997b), which has been used in various studies related to the implementation of educational technology such as computers, email, software and multimedia. TAT includes two sub-scales: the Stages of Adoption and the Teachers' Attitudes towards Technology sub-scales. Studies using the Stages of Adoption sub-scale include Christensen (1997a), Christensen and Knezek (1999), Christensen and Knezek (2001), Fraze, Fraze, Baker and Kieth (2002), and Knezek, Christensen, Hancock and Shoho (2000). Knezek and Christensen (1997a; 1997b; 1998a; 1998b) have used the Teachers' Attitudes Towards Technology sub-scale in their studies.

The second TAT sub-scale follows Zaichkowsky's (1985) Modified Personal Involvement Inventory (PII) and measures teachers' perceptions towards a particular technology. It focuses on the concept of interest and involvement, defined as "a person's perceived relevance of the object based on inherent needs, values, and interests" (Zaichkowsky, 1985, p. 342; Bei \& Simpson, 1995). Scores from this sub-scale are reversed before being averaged together to produce a single score. Research by Knezek, Christensen, Miyashita and Ropp (2000) has produced a high test-retest reliability estimate (0.91) for the Stages of Adoption sub-scale. In turn, work conducted by Knezek and Christensen (1998a) found a Cronbach's alpha internal reliability coefficient between 0.91 to 0.98 within items of the same sub-scale.

The questionnaire items were adapted to a GC context and subsequently piloted with four academic staff from the Faculties of Education at Macquarie and Wollongong Universities and ten school teachers. Respondents indicated their satisfaction with the semantic aspects of the items.

\section{Sample}

Six copies of the questionnaire were emailed to all 406 secondary schools administered by the NSW Department of Education and Training (DET), during September-October 2009. A pre-paid, self-addressed envelope accompanied the questionnaires along with a letter addressed to the school principal assuring anonymity and confidentiality. The letter requested school principals to pass on the questionnaires to the head teacher mathematics and the mathematics teachers in their schools who have taught or were currently teaching the Mathematics General Course, Years 11 or 12. Information for completing the form and details about the research study were also provided.

A total of $58 \%$ of schools returned the questionnaire and 587 teachers of the General Mathematics course participated in the study. Satisfactory return rates by DET region are shown on Table 1, adding strength to the data.

\section{Data analysis}

Descriptive statistics such as analysis of means and medians were used to characterise measures of central tendency among the variables. The dependent variable was stages 
of adoption. The independent variables were educational region, gender, educational qualifications, teaching experience, training, professional development modes, faculty support, perceptions of self competence, interest in using GCs in teaching and learning, and number of calculators. The relationship between variables and questionnaire items for the statistical analysis is shown Table 2.

Table 1: Survey return rate

\begin{tabular}{|l|c|l|c|}
\hline \multicolumn{1}{|c|}{ DET region } & $\%$ & \multicolumn{1}{c|}{ DET region } & $\%$ \\
\hline New England & 50 & South Western Sydney & 51 \\
\hline North Coast & 55 & Sydney & 58 \\
\hline North Sydney & 49 & Western NSW & 57 \\
\hline Riverina & 76 & Western Sydney & 58 \\
\hline South East Illawara & 68 & Hunters Central Coast & 65 \\
\hline
\end{tabular}

Table 2: Questionnaire items and variables

\begin{tabular}{|l|c|l|l|}
\hline \multicolumn{1}{|c|}{ Variable } & Item & \multicolumn{1}{c|}{ Question } \\
\hline Gender & Q1 & Gender \\
\hline Educational qualifications & Q2 & Highest completed educational qualifications \\
\hline Teaching experience & Q3 & Years of teaching experience \\
\hline Training & Q4 & Have you ever received any training on GCs? \\
\hline Professional development modes & Q5 & $\begin{array}{l}\text { Check the option that best describe your training on } \\
\text { GCs }\end{array}$ \\
\hline Support & Q6 & $\begin{array}{l}\text { What level of support exists in your faculty for using } \\
\text { GCs? }\end{array}$ \\
\hline Competence & Q7 & How would you rate your competence using GCs? \\
\hline Number of graphics calculators & Q8 & How many GCs does your school own? \\
\hline Interest & Q9 & $\begin{array}{l}\text { Choose one location between each adjective to indicate } \\
\text { how you feel about teaching and learning using GCs }\end{array}$ \\
\hline Stages of adoption & Q10 & $\begin{array}{l}\text { Please read the description of each of the six stages } \\
\text { related to the adoption of graphics calculators. Choose } \\
\text { the stage that best describes where you are at. }\end{array}$ \\
\hline
\end{tabular}

Through multiple regression analysis, the study looked at the degree of univariate correlation between the dependent variable (teachers' stages of adoption) and the set of independent variables as outlined above. The level of significance for all statistical tests was set at 0.01 (two-sided tests). The model was used for explaining and identifying the most important factors that correspond to higher stages of adoption. The qualitative analysis of teachers' responses to the open section of the questionnaire focused on the variables found to explain stages of adoption. Forty-three percent of the teachers contributed with their comments, suggesting a reasonable interest on the topic.

\section{Quantitative analysis results}

To facilitate the statistical analysis, scores were reversed to indicate a positive progression in responses to questionnaire items 6, 7 and 9. The median educational qualification range was a Diploma of Education plus a Bachelor Degree in any discipline. The median teaching experience range was 16-20 years. Around half (49\%) of the participants were female. The median faculty support range fell into the "Low" category range on a scale ranging from "None" to "Low", "Medium", and "High". Median perception of self-competence was "Satisfactory" on a scale ranging from "Incompetent" to "Satisfactory", "More competent than other", and "Very competent". 
The median range on the number of graphics calculators in school was 21-30 per school, which suggests about one class set of GCs for the whole school. Two-thirds of the participants reported having attended some professional development on using GCs and in response to the question, "What best describe your training on graphics calculators?", the following frequencies were obtained (Table 3).

Table 3: Professional development options

\begin{tabular}{|l|c|}
\hline \multicolumn{1}{|c|}{ Option } & Frequency \\
\hline Teacher journal/magazine & 4 \\
\hline College or university & 40 \\
\hline Peer/colleague & 76 \\
\hline School district office & 18 \\
\hline NSW or AAMT conferences & 35 \\
\hline Private GC company & 145 \\
\hline Teacher self-taught & 6 \\
\hline
\end{tabular}

Means of teachers' responses to the ten items of the interest sub-scale are shown in Table 4 . The scale ranged from 1 to 7 , with 7 being the highest possible positive score, and 4 representing a perception lying midway between strongly disagree and strongly agree. The data in Table 4 indicate opinions on the personal interest with GCs ranging between "somewhat disagree" and "somewhat agree".

Table 4: Teachers' interest on using graphics calculators

\begin{tabular}{|l|c|c|}
\hline \multicolumn{1}{|c|}{ Opinions } & Mean & S.D. \\
\hline Important & 3.92 & 1.817 \\
\hline Interesting & 4.71 & 1.525 \\
\hline Relevant & 4.28 & 1.723 \\
\hline Exciting & 4.06 & 1.521 \\
\hline Means a lot & 4.23 & 1.494 \\
\hline Appealing & 4.20 & 1.677 \\
\hline Fascinating & 4.01 & 1.498 \\
\hline Valuable & 4.55 & 1.533 \\
\hline Involving & 4.51 & 1.499 \\
\hline Needed & 3.94 & 1.869 \\
\hline
\end{tabular}

The median stage of adoption of GCs was 3 ("Understanding and application of the process") with Stages 1 and 2 containing $48.5 \%$ of the responses while the modal stage was 1 ("awareness"). Responses to the stage of adoption item are shown in Figure 1 which shows up the frequency in the lower stages.

Multiple regression was used to investigate the explanatory effect of each independent variable upon the dependent variable stages of adoption on the basis of their combined scores. The ten items of the interest sub-scale measuring opinions about the personal interest towards GCs were also included as independent variables, as in Table 4.

A stepwise multiple regression analysis was conducted to identify explanatory variables based on their contribution to the model. Beta coefficients measure how strongly each independent variable explains the dependent variable. Results in Table 5 show multiple regression beta coefficients for five independent variables that were found to significantly relate to the dependent variable, namely, competence $(p<.001)$, important $(p=.001)$, appealing $(p=.011)$, support $(p=.011)$ and training $(p=.003)$. 


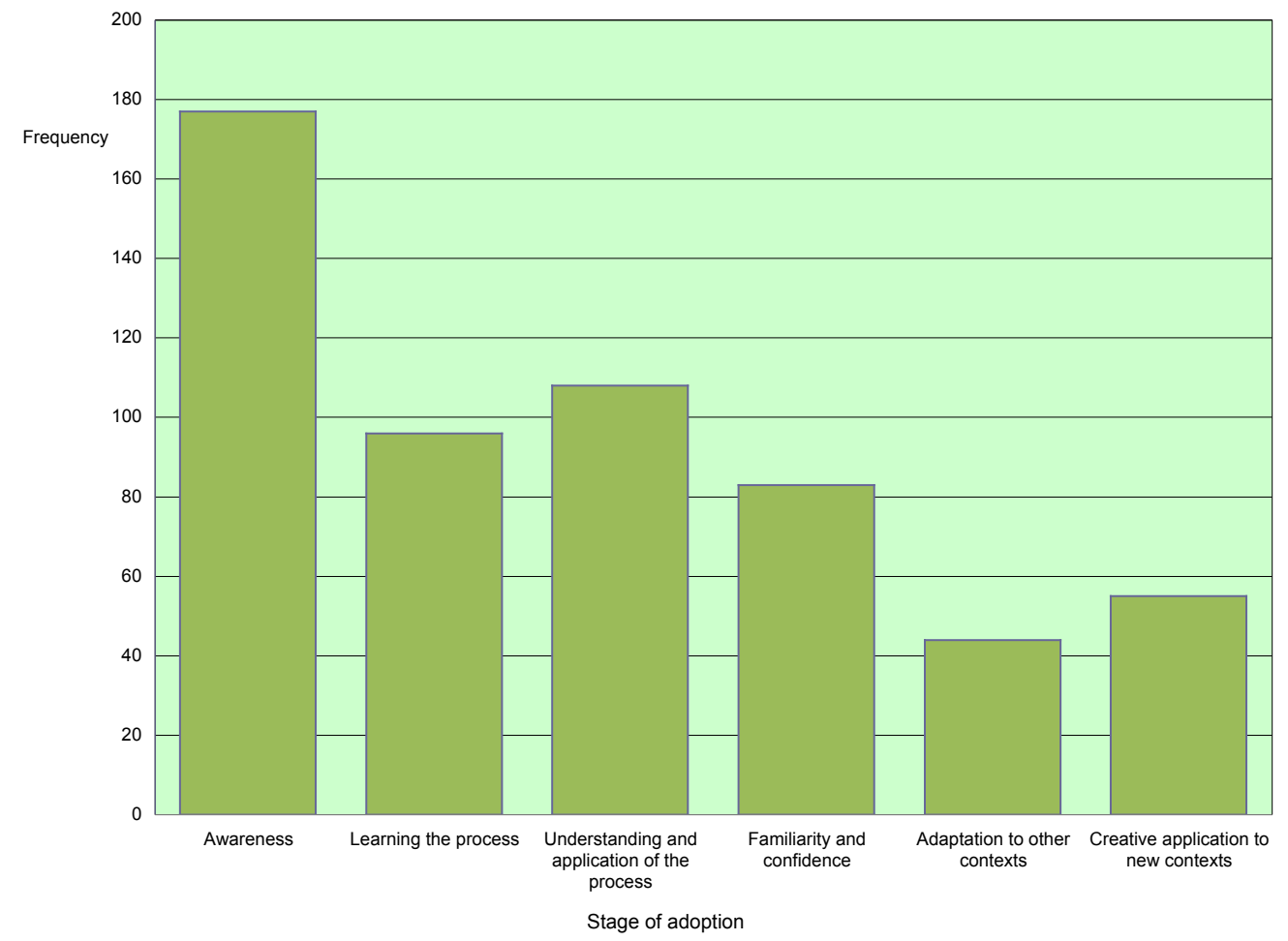

Figure 1: Stages of adoption frequencies

The results also reveal that the model is useful and a good fit for the data $\left(R=.811 ; R^{2}\right.$ $=.658$, adjusted $\left.R^{2}=.655, p<.001\right)$. Here, $R=.811$ stands for the multiple correlation coefficient while $R^{2}=.658$ indicates that $65.8 \%$ of the variability in stage of adoption can be explained by the combinations of all variables. The multiple regression beta coefficients indicate the average change on the dependent variable when all the other independent variables remain constant.

Table 5: Multiple regression coefficients (first model) Dependent variable: Stages of adoption

\begin{tabular}{|l|c|c|c|c|}
\hline \multicolumn{1}{|c|}{ Variables } & Beta & Std. error & $\mathrm{t}$ & Sig. \\
\hline (Constant) & -.645 & .136 & -4.739 & .000 \\
\hline Competence & 1.237 & .059 & 20.823 & .000 \\
\hline Important & .101 & .031 & 3.263 & .001 \\
\hline Appealing & .086 & .034 & 2.549 & .011 \\
\hline Support & .134 & .052 & 2.560 & .011 \\
\hline Training & 286 & .095 & 3.017 & .003 \\
\hline
\end{tabular}

A factor analysis was conducted among the ten items of the interest sub-scale to determine whether or not they measured the same construct. For semantic purposes, the construct is referred to as interest following Zaichkowsky's conceptualisation (Zaichkowsky, 1985, p. 342; Bei \& Simpson, 1995) as quoted in the Methodology section of this paper. The component matrix extracted a single factor which was corroborated by the eigenvalues plotted against the factor numbers on a scree plot. In general, a scree plot shows the number of factors suitable for a certain analysis before 
the plotted line turns abruptly to the right. Knezek and Christensen (1998a) also found a Cronbach's alpha internal coefficient of reliability between .91 and .98 for the combined ten items of the interest sub-scale. The factor extracted was used in further analysis.

A subsequent multiple regression analysis using the variable interest with the previously selected variables (competence, support, training) resulted in $R=.808, R^{2}=$ .653 , adjusted $R^{2}=.651 ; p=.000$. Such results were consistent with the previous stepwise analysis and therefore the four variables (competence, support, training and interest), were taken as the basis for explaining the statistical model for this study. Multiple regression coefficients are shown in Table 6.

Table 6: Multiple regression coefficients (refined model) Dependent variable: Stages of adoption

\begin{tabular}{|l|c|c|c|c|}
\hline \multicolumn{1}{|c|}{ Variables } & Beta & Std. error & $\mathrm{t}$ & Sig. \\
\hline (Constant) & -.743 & .152 & -4.872 & .000 \\
\hline Competence & 1.255 & .060 & 21.026 & .000 \\
\hline Support & .126 & .052 & 2.408 & .016 \\
\hline Training & .242 & .095 & 2.565 & .011 \\
\hline Interest & .202 & .035 & 5.235 & .000 \\
\hline
\end{tabular}

To corroborate the above results, an ordinal regression treating all exploratory variables as quantitative found the same four variables significant (though support has $p=0.048$, so marginal). Again, competence was the most important predictor, with an odds ratio of 9.67, while support, training and interest have ordinal regressions of 1.22, 1.69 and 1.52 respectively. When support and competence were treated as ordinal (for consistency), the coefficients were consistent with the above, and with similar distances between them (indicating that the variables could be treated as numeric).

In general, the most important explanatory variable in the model is competence - one step up corresponds to 1.26 steps up on the adoption scale, linear regression, or an odds ratio of nearly 10 , ordinal regression.

Finally, a univariate analysis of variance was used to investigate the possible differences in stage of adoption between different DET regions - a categorical independent variable not included in the multiple regression; this was carried out with the four previously identified explanatory variables (competence, support, training and interest) as covariates. Since region had a non-significant $p$-value (0.39), it did not seem to be required in the model.

\section{Qualitative analysis results}

The quantitative results in Table 6 are important because they identify four variables that explain around two-thirds of the variability in stages of adoption. These variables are: perceptions of self competence (or competence, for the sake of brevity), faculty support, training and personal interest towards GCs. Furthermore, perception of self competence is identified as the most important factor, suggesting that one more step on the competence scale yields an increment of 1.26 on the stage of adoption scale. Similarly, increments by a quarter on the stages of adoption scale can possibly be attributed to training. Minor increments occurred due to personal interest and faculty support effects. 
A subsequent qualitative analysis examined teachers' responses to the open ended section of the questionnaire in regard to the four aforementioned explanatory variables.

\section{Competence and training}

It seems logical to relate perceptions of self competence to training because one naturally follows the other, provided that professional development is systematic, contextualised and sustainable. As some teachers stated:

I would be keen and confident enough to use the graphics calculators, but haven't been exposed to them yet. It is a positive move forward and would help relate to my current use and increasing knowledge of smart board technology.

Unless I can use something proficiently, I am not comfortable teaching it. I have had a couple of inservices, but they only skim the surface. They don't prepare you for classroom use.

We need ongoing support if we are to use the calculators. One-off training sessions are not good enough.

The average age of a public school teacher in NSW is 47 years (Handal, Chinnappan \& Herrington, 2004), so most teachers have left their teaching training long ago. In addition, the median teaching experience in this study ranges between 16-20 years, so it is likely that many teachers have not been sufficiently exposed to learning technologies such as GCs. The lack of teacher professional development is exacerbated by the fact that most teachers in the study undertook training through private companies, where sessions are typically not more than two hours in duration.

In fact, teachers' comments in the open section of the questionnaire indicate a demand for more integrated professional development programs on GCs:

Teacher education on how to use graphics calculators properly for specific tasks is lacking. Most of us are expected to use graphics without any real instruction on how to use them. We are learning after the fact - this is not good enough - the same is true for the new laptop introduction - EDUCATE TEACHERS FIRST, many of us are willing we just need help.

The inservice I had was nine years ago and due to that and lack of practice I've forgotten how to use them. A brush up would be good, but teachers do get little time to do things like that without a fair bit of pushing (especially older ones like me!).

\section{Faculty support}

Lack of faculty support for using GCs in the classrooms is illustrated by the following comments:

The implementation of GC in secondary schools is completely dependent upon the executive's attitude towards the expense and effort.

School based support/ excitement for using these calculators is nil. I use them at uni, and can see how they would be exciting and very enriching for advanced/extension students. Our class set of graphics calculators is sitting underneath the computer table in our staffroom gathering dust. Sad.

There hasn't been enough push for using graphics calculators from above. 


\section{Perceived personal interest with GCs}

A diversity of controversial and conflictive opinions about the role of GCs in instruction is revealed in teachers' responses to the open section of the questionnaire. Such contradictions are also reflected in the quantitative results of the interest sub-scale in Table 4 where two of the items yielded scores less than 4 (out of a maximum five points) such as important (mean score $=3.92$ ) and needed (mean score $=3.94$ ). Also the statistical analysis in Table 5 shows that importance and appealing were found as the least influential factors in explaining stages of adoption.

Firstly, some teachers are interested in GCs because they bring the visual and modelling dimensions into the teaching and learning of secondary mathematics.

2009 is the first year our school has purchased and used graphics calculators for our General students. I can see the benefits of using these calculators, allowing band 3 students to access and attempt some band 5 and 6 questions.

Graphics calculators provide an opportunity for students to explore mathematical understanding with less teacher direction.

Graphics calculators are a great tool to reinforce/support most concepts.

Other teachers feel that GCs are not relevant to instruction but rather inhibit the development of problem solving, computational and graphing skills.

Graphics calculator use means students are not using their brains to think and problem solve. The technology is doing all the thinking and solving for them. It is another piece of technology that is aiding in the 'dumbing down' of teaching and learning.

I firmly believe that they encourage poor learning with regard to certain skills due to a loss of hand-written graphing abilities. These are good for demonstrating after these basic skills have been learnt - not before.

Yet, there is another group of teachers who believe that GCs are relevant only to more advanced students:

I feel that graphics calculators are far more useful for more academic students. Using graphics calculators without basic understanding of concepts I believe is useless!

I am competent using graphics calculators BUT I do not believe they have a place in the General Maths Course. I do believe they have a role which could be played in the more "Pure" mathematics course assuming that questions are written which require working to be shown. As an introduction tool I find other graphics programs \& data projector more useful.

Perceived interest with GCs is also expressed in terms of students' ownership and affordability:

Our students don't own graphics calculators, so they won't use them in HSC. Hence used in very limited way by faculty.

Until they are made freely available to all students then I do not believe they should be allowed.

Another group of teachers feels that GCs are not relevant because their use is not permitted in the examinations for the other three NSW HSC mathematics courses. 
Among all Australian states and territories, NSW is the only one which does not allow all students to use GCs in their end of school examinations. In this regard, teachers' comments illustrate that opinion:

Graphics calculators are not allowed in HSC examination (and consequently trial and assessment tasks) so the importance given to them and their use in classrooms is low. Students are still required, in examinations, to work without this tool. To me this presents a conflict between teaching and preparation for the HSC examination.

As the HSC for gen[eral] maths still requires candidates to show working into a specific formula, the need for graphics calculators in exams is minimal (if at all).

The advent of the National Curriculum and the nationwide standardisation of those examinations and technology and teaching requirements might make the implementation of GCs a priority for the NSW Department of Education and has put some faculties on hold. As a teacher put it:

We are now looking to the National curriculum and what calculators will be specified.

Nevertheless, teachers from other states illustrate their feelings about their instructional skills with GCs and what they came to experience in NSW:

We do not have any graphics calculators at our school. I have used them when I taught in Qld and found them very valuable.

I have come from Victoria where we have used GCs for at least 15 yrs across all HSC courses, including in exams. I am shocked at the lack of use of technology in the NSW Maths curriculum, certainly at my school.

Finally, the interest towards using GCs in teaching and learning mathematics is being challenged by the arrival of laptops and free web applications which appear to render the same functions, although with obvious restrictions in portability and compactness. Some teachers stated:

There are better computer based software like Geogebra which can interface with other softwares like Microsoft Word and web browsers. This provides wider applications than graphics calculators. Graphics calculators are good for its compactness.

Computer software/IRW more relevant. With many schools having access to technology such as computers and ever developing software, combined with the expense and lack of students ownership, the use of these is becoming less relevant to students and teaching.

Prefer to use computer graphing. Find calculators screen too pixelated. They're not used in work so don't feel they're too important. The menu system is not intuitive too time consuming to learn.

\section{Discussion and conclusions}

This study has shown that personal expertise, positive attitudes and faculty support in using GCs are vital to adoption. Furthermore, it has revealed that traditional differential effects in education such as gender, educational qualifications, geographical location and availability of technology did not play an important role in increasing adoption of GCs, as some may have expected. 
It is noteworthy that the four explanatory variables (competence, support, training and interest) seem to be related to the concept of personal expertise, as opposed to the other variables that were found statistically non-significant, such as educational region, gender, qualifications, teaching experience, and number of calculators in the school. One might argue that these last five variables appear more system related and therefore more difficult for an individual teacher to change, at least in the short term.

The results of the study are discouraging. After ten years of the General Mathematics course in NSW, the teachers are still in the "Understanding and application of the process" stage, the third lowest on a six-point scale. This is much lower than the adoption levels reported by Fraze, Fraze, Baker and Kieth (2002) researching Internet technologies usage, and Christensen and Knezek (2001) investigating a broader range of educational technologies. In addition, in the present study the average number of GCs was 21-30 which makes only one class set per school, while the average level of faculty support is reported as "Low". Most of the professional development reported by teachers was sporadic and left in the hands of commercial firms and professional associations.

Teachers seem to be caught in an official contradiction: they believe that GCs are good for learning and teaching in the General Mathematics course but are not acceptable in the other three Calculus courses (Mathematics "2-Unit", Extension 1 and Extension 2), probably because either they are seen to be detrimental to learning or because of the disalignment between assessment and classroom practice. These dilemmas, a form of hidden curriculum, influence teachers' opinions on getting interested and involved with Gcs, causing a conflict as revealed in some of the teachers' comments. This also might be reason why most teachers' opinions about their interest, defined as "a person's perceived relevance of the object based on inherent needs, values and interests" (Zaichkowsky, 1985, p. 342), with GCs ranged between "somewhat disagree" and "somewhat agree".

Many reservations about GCs appear to be centred on de-skilling students, a common complaint against the use of technologies, corroborating results reported by Goos and Bennison (2008) and Thomas, Hong, Bosley and delos Santos (2008). It follows that teachers need to be reassured that technology can be useful for developing higher order learning skills Professional development activities should be pitched at the highest level of adoption where teachers can creatively use GCs as an instructional tool and integrate it into the curriculum. As one teacher commented, "Knowing how to use a wheelbarrow does not make you a good gardener."

Other issues emerging from the research are equity and the advent of other learning technologies. Will GCs survive alongside free web applications, laptops and touch and mobile devices? Excel spreadsheets, software like Winplot and GCs have coexisted in schools for many years as modelling and graphing tools, although GCs have the advantage of compactness, particularly for examination purposes. On the another hand, teachers' demands for GCs with more intuitive navigation, affordability, online connections and better compatibility with other interfaces are valid and need to be addressed by manufacturers, particularly since the NSW DET has announced that from 2010 each Year 9 student will receive a laptop under the Laptops4Learning (L4L) program (NSW DET, 2009).

It is interesting to note that the number of GCs in a school did not come up as an explanatory factor in the adoption model, although a previous study on computers 
(Thomas, 2006), making use of descriptive statistics, indicated the importance that teachers ascribe to resourcing. In fact, many teachers' comments in the open section of the questionnaire complained about the small number of GCs owned by the school, as well as the prohibitive cost of a GC for students from disadvantaged backgrounds. The lack of student personal ownership of GCs is certainly an issue. Yet, at the school resourcing level, there is evidence from the responses that even when GCs are made available, they are not being utilised. Furthermore, it can be argued that a productive and vibrant mathematics lesson can be run with only one GC, so long as it is operated by a resourceful teacher in interaction with the class.

An important point is that simply stocking schools with new technologies will not necessarily lead to their automatic adoption or most effective adoption. In general, building teachers' competence with the technology is vital (Forgasz, 2002; Thomas, 2006). As corroborated in this study, the most explanatory factor in the adoption model was perception of self competence. In general, competence is best achieved through systematic, sustained and accessible professional development. Such training endeavours must focus not only on GCs navigational aspects but also on using the technology productively and creatively, so that teachers are assured of its instructional value.

\section{Appendix: Questionnaire}

Appendix: Questionnaire is contained in the accompanying file 'handal-appendix.pdf', URL http:/ / www.ascilite.org.au / ajet/ ajet27/handal-appendix.pdf

\section{References}

Alguire, H. \& Forster, P. A. (1999). Promoting mathematical understanding through the use of graphics calculators. Proceedings of the Australian Curriculum, Assessment and Certification Authorities Conference (pp. 131-144). Perth: Curriculum Council.

Arnold, S. (2004). Mathematics education for the third millennium: Visions of a future for handheld classroom technology. In I. Putt, R. Faragher \& M. McLean (Eds.), Mathematics education for the third millennium: Towards 2010. Proceedings of the 27th annual conference of the Mathematics Education Research Group of Australasia, pp. 16-28. Sydney: MERGA. http: / / www.merga.net.au/ documents / keynote22004.pdf

Atkin, D. J., Neuendorf, K., Jeffres, L. W. \& Skalski, P. (2003). Predictors of audience interest in adopting digital television. Journal of Media Economics, 16(3), 159-173.

Bei, L. \& Simpson, E. (1995). The determinants of consumers' purchase decisions for recycled products: An application of acquisition-transaction utility theory. In F. Kardes and M. Sujan (Eds.), Advances in consumer research (pp. 257-261). Provo, UT: Association for Consumer Research.

Board of Secondary Education NSW (1981). 2 Unit Mathematics in Society Course. Sydney: Secondary Schools Board.

Board of Secondary Education NSW (1989). Mathematics in Practice Syllabus. Sydney: Secondary Schools Board.

Board of Studies NSW (1999). General Mathematics Stage 6 syllabus. Sydney: BOS.

Burril, G. (1992). The graphing calculator: A tool for change. In J. T. Fey \& C. R. Hirsch (Eds.), Calculators in Mathematics Education (pp. 14-22). Reston, Va: National Council of Teachers of Mathematics. 
Bussey, J. M., Dormody, T. J. \& VanLeeuwen, D. (2000). Some factors predicting the adoption of technology education in New Mexico public schools. Journal of Technology Education, 12(1). [verified 21 Apr 2011] http: / / scholar.lib.vt.edu/ejournals/JTE/v12n1/bussey.html

Cafolla, R. \& Knee, R. (1995). Factors limiting technology integration in education: The leadership gap. Technology and Teacher Education Annual, 556-560.

Cavanagh, M. \& Mitchelmore, M. (2003). Graphics calculators in the learning of mathematics: Teacher understandings and classroom practices. Mathematics Teacher Education and Development, 5, 3-18.

Clarke, T. (2001). Spreadsheet assessment tasks for General Mathematics. Reflections, 26(1), 31-32.

Christensen, R. (1997a). Effect of technology integration on the attitudes of teachers and their students. Doctoral dissertation, University of North Texas. [viewed 29 July 2010, verified 21 Apr 2011]. http: / / courseweb.unt.edu/rhondac/research/dissert/index.htm

Christensen, R (1997b). The Teachers' Attitudes Toward Information Technology Questionnaire version 2.0. Denton, TX: University of North Texas and the Texas Center for Educational Technology. [verified 21 Apr 2011] http:/ / www.tcet.unt.edu/insight/ilib/soa/

Christensen, R. \& Knezek, G. (1999). Stages of adoption for technology in education. Computers in New Zealand Schools, 11(3), 25-29.

Christensen, R. \& Knezek, G. (2001). Equity and diversity in K-12 applications of information technology: KIDS project findings for 2000-2001. Institute for the Integration of Technology into Teaching and Learning. [viewed 29 July 2010, verified 21 Apr 2011] http: / / www.iittl.unt.edu/KIDS2001/index.htm

Ertmer, P.A., Addison, P., Lane, M., Ross, E. \& Woods, D. (1999). Examining teachers' beliefs about the role of technology in the elementary classroom. Journal of Research on Computing in Education, 32, 54-72.

Evans-Andris, M. (1995). An examination of computing styles among teachers in elementary schools. Educational Technology Research E Development, 43(2), 15-31.

Featherman, M. \& Pavlou, P. (2003). Predicting e-services adoption: A perceived risk facets perspective. International Journal of Human-Computer Studies, 59(4), 451-474. [verified $21 \mathrm{Apr}$ 2011] http:/ / sighci.org/amcis02/CR/Featherman.pdf

Forgasz, H. \& Prince, N. (2001). Computers for secondary mathematics: Who uses them and how? Proceedings of the 2001 Annual Conference of the Australian Association for Research in Education, Fremantle, WA. [viewed 10 Jun 2003, verified 21 Apr 2011] http: / / www.aare.edu.au/01pap/ for01109.htm

Forgasz, H. (2002). Teachers and computers for secondary mathematics. Education and Information Technology, 7(2), 111-125.

Forgasz, H., Griffith, S. \& Tan, H. (2006). Gender, equity, teachers, students and technology use in secondary mathematics classrooms. Proceedings of the Nineteenth ICMI Conference Technology Revisited (p. 72). Hanoi Institute of Technology. [verified 21 Apr 2011] http: / / elib.lhu.edu.vn/ bitstream/123456789/4764/1/c82.pdf

Fraze, S., Fraze, D., Baker, M. \& Kieth, L. (2002). Texas agri-science teachers' attitude toward and stage of adoption of the Internet. Journal of Southern Agricultural Education Research, 52, 62-73. [verified 21 Apr 2011] http: / / www.jsaer.org/pdf/Vol52/52-02-062.pdf

Galbraith, P., Renshaw, P., Goos, M. \& Geiger, V. (1999). Technology, mathematics and people: Interactions in a community of practice. In J. Truran \& K. Truran (Eds.), Making the difference. Proceedings of the Twenty-second Annual Conference of the Mathematics Education Research Group of Australasia (pp. 223-230). Melbourne: MERGA. 
Geiger, V. \& Goos, M. (1996). Number plugging or problem solving? Using technology to support collaborative learning. In P. Clarkson (Ed.), Technology and Mathematics Education. Proceedings of the Nineteenth Annual Conference of the Mathematics Education Research Group of Australasia, (pp. 10-19). Melbourne: MERGA. [verified 21 Apr 2011] http: / / www.merga.net.au/documents/RP_Geiger_Goos_1996.pdf

Goos, M. \& Bennison, A. (2007). Technology-enriched teaching of secondary mathematics: Factors influencing innovative practice. In J. Watson \& K. Beswick (Eds.), Mathematics: Essential research, essential practice (Proceedings of the 30th annual conference of the Mathematics Education Research Group of Australasia, pp. 315-324). Adelaide: MERGA. [verified 21 Apr 2011] http: / / www.merga.net.au/documents / RP262007.pdf

Goos, M. \& Bennison, A. (2008). Surveying the technology landscape: Teachers' use of technology in secondary mathematics classrooms. Mathematics Education Research Journal, 20(3), 102-130. http: / / www.eric.ed.gov:80 / ERICWebPortal/ contentdelivery / servlet / ERICServlet?accno=EJ836455

Griffith, S. (2007). Graphing calculators in the mathematics classroom: Methods, sample, instrument and analyses. Vinculum, 44(2), 14-19.

Grove, M. (2001). General Maths: What's in it? Reflections, 26(1), 24-26.

Hadley, M. \& Sheingold, K. (1993). Commonalities and distinctive patterns in teachers' integration of computers. American Journal of Education, 101(3), 261-315.

Handal, B., Bobis, J. \& Grimison, L. (2001). Teachers' mathematical beliefs and practices in teaching and learning thematically. In J. Bobis, B. Perry \& M. Mitchelmore (Eds.), Numeracy and beyond. Proceedings of the Twenty-Fourth Annual Conference of the Mathematics Education Research Group of Australasia Inc (pp. 265-272), Sydney: MERGA.

Handal, B. \& Herrington, T. (2003). Mathematics teachers beliefs and curriculum reform. Mathematics Education Research Journal, 15(1), 59-69. http:/ / www.merga.net.au/documents/MERJ_15_1_Handal.pdf

Handal, B. (2004). Teachers' instructional beliefs about integrating educational technology. EJournal of Instructional Science and Technology, 7(1). http:// www.ascilite.org.au/ajet/ejist/docs/Vol7_No1/Commentary/Teachers_ins_beliefs.htm

Handal, B., Chinnappan, M. \& Herrington, T. (2004). Measuring the adoption of graphic calculators by secondary mathematics teachers. Proceedings of the 2 nd National Conference on Graphing Calculators (pp. 29-43). University Sains Malaysia. http: / / math.usm.my/Events/NCGC04Proc/ PDF/BorisHandal.pdf

Hennessy, S., Fung, P. \& Scanlon, E. (2001). The role of the graphic calculator in mediating graphing activity. International Journal of Mathematical Education in Science and Technology, 32(2), 267-290.

Hudson, R., Porter, A. \& Nelson, M. (2008). The view of secondary school mathematics teachers in Australia regarding the use of technology in the classroom. In J. Luca \& E. Weippl (Eds.), Proceedings of World Conference on Educational Multimedia, Hypermedia and Telecommunications 2008 (pp. 5771-5777). Chesapeake, VA: AACE.

Knezek, G. \& Christensen, R. (1997a). Internal Consistency Reliability for the Teachers' Attitudes Toward Information Technology (TAT) Questionnaire. Denton, TX: Texas Center for Educational Technology.

http: / / www.iittl.unt.edu/IITTL/newiittl/iittl_instruments / tat/internal_consistency.htm

Knezek, G., \& Christensen, R. (1997b). Attitudes Toward Information Technology at Two Parochial Schools in North Texas. Denton, TX: Texas Center for Educational Technology. http: / / www.iittl.unt.edu/IITTL/ newiittl/iittl_instruments / tat/attitudes_toward_informati on.htm 
Knezek, G., \& Christensen, R. (1998a). Internal Consistency Reliability for the Teachers' Attitudes Toward Information Technology Questionnaire. Panel presented at the Society of Information Technology \& Teacher Education (SITE) 9th International Conference, Washington, DC, March 13, 1998.

Knezek, G., \& Christensen, R. (1998b). Attitudes Towards Information Technology Among Teachers at Six Texas Middle Schools. Denton, TX: Texas Center for Educational Technology. http:/ / www.iittl.unt.edu/IITTL/newiittl/iittl_instruments/tat/attitude_toward_information1.htm

Knezek, G., Christensen, R., Hancock, R. \& Shoho, A. (2000). Toward a structural model of technology integration. Proceedings of the Hawaii Educational Research Association.

Kwon, O. N. (2002). The effect of calculator-based ranger activities on students' graphing ability. School Science and Mathematics, 102(2), 57-67.

Loong, E. (2003). Australian secondary school teachers' use of the Internet for mathematics. In L. Bragg, C. Campbell, G. Herbert \& J. Mousley (Eds.), Mathematics education research: Innovation, networking, opportunity (Proceedings of the 26th annual conference of the Mathematics Education Research Group of Australasia, pp. 484-491). Sydney: MERGA. http: / / www.merga.net.au/documents/RR_loong.pdf

Maddux, C. D., LaMont Johnson, D. \& Willis, J. W. (1997). Educational computing: Learning with tomorrow's technologies. (2nd Ed.). Needham Heights: Allyn \& Bacon.

Ndubisi, N. (2004). Factors influencing e-learning adoption intention: Examining the determinant structure of the decomposed theory of planned behaviour constructs. In Transforming knowledge into wisdom. Proceedings of the 27th HERDSA Annual Conference, Miri, Sarawak, 4-7 July, pp 252. http: / / www.herdsa.org.au / conference2004 / Contributions / RPapers / P057-jt.pdf

NSW Department of Education and Training (NSW DET) (2009). Connected Learning: Secondary Schools Laptop Program. [viewed 29 July 2010, verified 21 Apr 2011]. https:/ / www.det.nsw. edu.au/media/downloads/strat_direction/schools/dernsw/news/clbulletin01.pdf

Osborne, J. W. (2000). Prediction in multiple regression. Practical Assessment, Research $\mathcal{E}$ Evaluation, 7(2). http:/ / pareonline.net/ getvn.asp? $\mathrm{v}=7 \& \mathrm{n}=2$

Pender, B. (2000). Some words of caution about graphics calculators. In W. Mollony \& M. Stephens (Eds.), Students, mathematics and graphics calculators into the new millennium. Proceedings of the 2003 Australian Association of Mathematics Teachers Inc. (pp. 163-167). Sydney: AAMT. [viewed 29 July 2010, verified 21 Apr 2011, $1.8 \mathrm{MB}$ ]. http:/ / www.aamt.edu.au/content/download/1000/22963/file/gc-proc.pdf

Portafoglio, A. (1998). The effects of pair collaboration in community college computer calculus laboratories. Unpublished Doctoral dissertation, Columbia University Teachers College). Dissertation Abstracts International. 59, O74, 2407.

Routitsky, A. \& Tobin, P. (1998). A survey of graphics calculator use in Victorian secondary schools. In C. Kanes, M. Goos \& E. Warren (Eds.), Teaching mathematics in new times. Proceedings of the 21st annual conference of the Mathematics Education Research Group of Australasia, pp. 484-491. Gold Coast: MERGA.

Russell, A. L. (1995). Stages in learning new technology: Naive adult email users. Computers $\mathcal{E}$ Education, 25(4), 173-178.

Shah Azam, Md. (2007). Internet adoption and usage in Bangladesh. Japanese Journal of Administrative Science, 20(1), 43-54.

Simonsen, L. M. \& Dick, T. P. (1997). Teachers' perceptions of the impact of graphic calculators in the mathematics classroom. Journal of Computers in Mathematics and Science Technology, 16, 239-268. 
Thomas, M. O. J. (2006). Teachers using computers in mathematics: A longitudinal study. In J. Novotna, H. Moraova, M. Kratka, \& N. Stehlikova (Eds.), Proceedings of the 30 th annual conference of the International Group for the Psychology of Mathematics Education (Vol. 5, pp. 265272). Prague: PME.

Thomas, M. O. J., Hong, Y. Y., Bosley, J. \& delos Santos, A. (2008). Use of calculators in the mathematics classroom. The Electronic Journal of Mathematics and Technology, 2(2), 1-6.

Tobin, P., Routitsky, A. \& Jones, P. (1999). Graphics calculators in Victorian secondary schools: Teacher perceptions of use. In J. Truran \& K. Truran (Eds.), Making the difference. Proceedings of the 22 nd annual conference of the Mathematics Education Research Group of Australasia, pp. 502506. Sydney: MERGA.

Vonder Embse, C. (1992). Concept development and problem solving using graphing calculators in the middle school. In J. T. Fey \& C. R. Hirsch (Eds.), Calculators in mathematics education (pp. 65-78). Reston, Va: National Council of Teachers of Mathematics.

Weber, T.E. (1998). Graphing technology and its effect on solving inequalities. Unpublished Doctoral dissertation. Wayne State University. Dissertation Abstracts International, 60, 01A, 88.

Zaichkowsky, J. (1985). Measuring the involvement construct. The Journal of Consumer Research, $12,341-352$.

Authors: Dr Boris Handal, University of Notre Dame Australia

104 Broadway (PO Box 944), Broadway NSW 2007. Email: boris.handal@nd.edu.au

Dr Michael Cavanagh, Macquarie University, NSW 2109

Email: michael.cavanagh@mq.edu.au

Associate Professor Leigh Wood, Macquarie University, NSW 2109

Email: leigh.wood@mq.edu.au

Associate Professor Peter Petocz, Macquarie University, NSW 2109

Email: peter.petocz@mq.edu.au

Please cite as: Handal, B., Cavanagh, M., Wood, L. \& Petocz, P. (2011). Factors leading to the adoption of a learning technology: The case of graphics calculators. Australasian Journal of Educational Technology, 27(2), 343-360.

http: / / www.ascilite.org.au/ajet/ajet27/handal.html 